\title{
Gastrointestinal Replacement Solution
}

\author{
E. A. BADOE, ${ }^{*}$ M.B., F.R.C.s., D.T.M.\&H.
}

Summary: The mean sodium concentration of 61 $\checkmark$ gastrointestinal aspirations in peritonitis was $103 \mathrm{mEq} / 1$. (S.D. 16.66), of 16 aspirations in vagotomy $88 \mathrm{mEq} / 1$. (S.D. 19.49), of 12 aspirations in perforated duodenal ulcer $81 \mathrm{mEq} / 1$. (S.D. 19.49), and of 15 aspirations in intestinal obstruction $89 \mathrm{mEq} / 1$. (S.D. 19.49). The mean potassium concentrations were $9,9.9,13$, and $8.8 \mathrm{mEq} / 1$. respectively, and the mean chloride concentrations 122, 131, 125, and $112 \mathrm{mEq} / \mathrm{l}$. respectively. It is suggested that a gastrointestinal replacement solution should contain $100 \mathrm{mEq}$ of sodium, $12 \mathrm{mEq}$ of potassium, and $122 \mathrm{mEq}$ of chloride per litre; $50 \mathrm{~g}$. of dextrose or $100 \mathrm{~g}$. of fructose may be added to provide energy.

\section{Introduction}

The aim of replacement fluid therapy is to prevent electrolyte and water imbalances. Gastrointestinal aspirations commonly necessitated in surgery by conditions such as intestinal obstruction, paralytic ileus from diverse causes, and gastrointestinal surgery will result in metabolic problems if not properly replaced. The British practice appears to replace such losses volume for volume with normal saline, adding some potassium when necessary. Randall (1967), in the U.S.A., recommended replacement with varying mixtures of dextrose in water, dextrose in normal saline, $M / 6$ lactate, or sodium bicarbonate with $20 \mathrm{mEq}$ of potassium chloride per litre, the composition of the mixture depending on whether the loss is gastric, intestinal, biliary, or pancreatic. Cooke and Crowley (1952) suggested a gastric solution and an intestinal solution for replacement of gastric and intestinal losses, the solution used depending on the location of the drainage tube. Gastrointestinal decompression as practised in most hospitals, however, aspirates a mixture of gastric, intestinal, biliary, and pancreatic secretions except in gastroduodenal stenosis, when the aspiration is purely gastric. An attempt has therefore been made to determine the mean electrolyte concentration of such losses with a view to suggesting a solution suitable for the replacement of gastrointestinal aspirations.

\section{Patients and Methods}

Aspirations from patients on gastrointestinal decompression for acute intestinal obstruction, paralytic ileus following generalized peritonitis from diverse causes, and vagotomy with drainage were used for the study. Aspirations from vagotomy patients were used only after they had become macroscopically free of blood, usually after 48 hours. The $24-$ hour aspirations from each patient were pooled, and if the amount was over $500 \mathrm{ml}$. the sodium, potassium, and chloride concentrations were estimated. If the 24-hour collection was less than $500 \mathrm{ml}$. then the next 24-hour collection was added to it. Most of the aspirations were in fact over 1 litre. It was hoped that by using such large, and 24-hour, collections a fair estimate of the electrolyte losses would be obtained. The sources of the 104 specimens obtained are given in Table I. The age distribution of the 66 patients is shown in Table II. * Associate Professor, Department of Surgery, University of Ghana Medical
School, Accra, Ghana.

\section{Results}

Sodium.-The mean sodium concentration of gastrointestinal aspirations in peritonitis is given in Table III. The mean sodium concentration of aspirations in peritonitis is significantly different from those in vagotomy and drainage $(0.05>P>0.02)$, perforated duodenal ulcer $(0.01>P>0.001)$, and intestinal obstruction $(0.1>P>0.05)$. There is no significant difference in the sodium concentrations in vagotomy with drainage, perforated duodenal ulcer, and intestinal obstruction.

Potassium.-The mean potassium concentration of the aspirations in peritonitis is given in Table III. There is no significant difference between peritonitis, vagotomy with drainage $(0.7>P>0.6)$ and intestinal obstruction $(0.6>P>0.5)$. The difference between peritonitis and perforated duodenal ulcer is only just significant $(0 \cdot 1>\mathrm{P}>0.05)$.

Chloride.-The chloride concentrations in peritonitis, vagotomy with drainage, perforated duodenal ulcer, and intestinal obstruction are $122,131,125$, and $112 \mathrm{mEq} / \mathrm{l}$. respectively. There is no significant difference between them.

TABLE I.-Gastrointestinal Aspirations

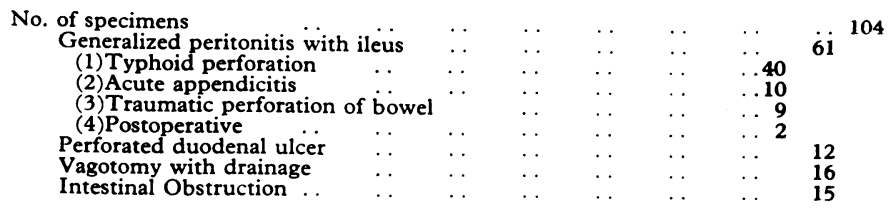

TABle II.-Age Distribution of Patients. Range 3-75 Years

\begin{tabular}{cccc|c|c|c} 
Age & & & & Male & Female & Total \\
\hline $0-9$ &. &. &. & 5 & 5 & 10 \\
$10-19$ &. &. &. & 12 & 3 & 15 \\
$20-29$ &. &. &. & 20 & 1 & 21 \\
$30-39$ &. &. &. & 6 & 4 & 10 \\
$40+$ &. &. &. & 8 & 2 & 10 \\
\hline Total &. &. &. & 51 & 15 & 66 \\
\hline
\end{tabular}

TABLE III.-Electrolyte Concentration of Gastrointestinal Aspirations

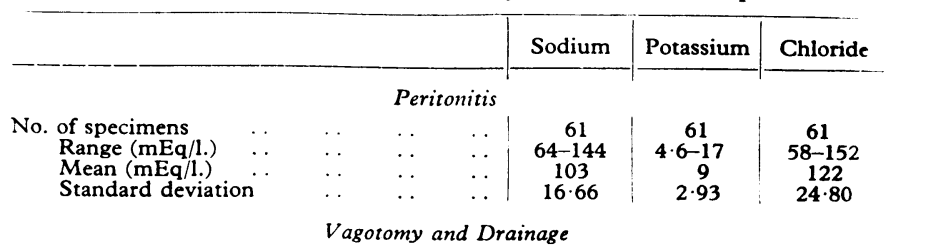

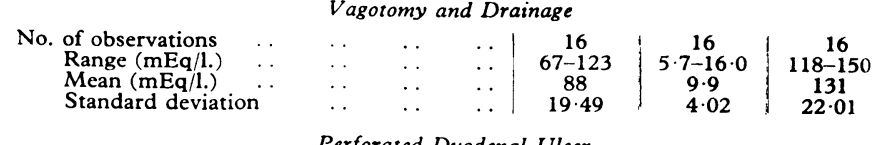
No. of observations
Range (mEq/1.)
Mean (mEq/1.) Standard deviation

Perforated Duodenal Ulcer

No. of observations
Range (mEq/1.)
Mean (mEq/l.) Mean (mEq/1.)
Standard deviation 
Electrolyte Concentration in Children under 10.- In these 10 children (nine typhoid perforation and one intestinal obstruction) the mean electrolyte concentrations were sodium $106(93-120) \mathrm{mEq} / 1$., potassium $9 \cdot 2(6 \cdot 1-17) \mathrm{mEq} / \mathrm{l}$, and chloride $107(84-128) \mathrm{mEq} / \mathrm{l}$. The ranges were thus narrower than in the adults, but the mean concentrations did not differ significantly from those of the whole series.

Electrolyte Concentrations in 11 Patients with Three or Four Specimens.-In 11 patients three or four 24-hourly specimens were obtained, and the results (Table IV) show the well-known daily variations in the electrolyte concentrations of gastrointestinal secretions in the individual. The mean sodium for each individual, except No. 4, however, does not vary significantly from the mean of his pathological group.

\section{Discussion}

As the electrolyte concentrations of gastrointestinal aspirations vary daily the ideal method for replacing such aspirations would be to estimate the total daily electrolyte and fluid losses for the individual patient and replace them. But, apart from the cost and the expense in time, it is doubtful, as shown in Table IV, whether the results would vary significantly from the mean of a large series.

It is evident from this study that the current practice of replacing such losses with normal saline (sodium $154 \mathrm{mEq} / \mathrm{l}$, chloride $154 \mathrm{mEq} / \mathrm{l}$.) provides more sodium and chloride than is necessary and may in part account for the oedema and stiffness of the gut often noted on reopening the abdomen.

TABLE IV.-Electrolyte Concentrations $(m E q / l$.) in 11 Patients with 3 or 4 Specimens. Nos. 1-6 Peritonitis, Nos. 6-8 Vagotomy and Drainage, Nos. 9 and 10 Perforated Duodenal Ulcer, and No. 11 Intestinal Obstruction

\begin{tabular}{|c|c|c|c|c|c|c|c|}
\hline \multicolumn{2}{|l|}{ No. } & & Spec. 1 & Spec. 2 & Spec. 3 & Spec. 4 & Mean \\
\hline \multicolumn{8}{|c|}{ Sodium } \\
\hline $\begin{aligned} 1 & \ldots \\
2 & \cdots \\
3 & \cdots \\
4 & \cdots \\
5 & \cdots \\
6 & \cdots \\
7 & \cdots \\
8 & \cdots \\
9 & \cdots \\
10 & \cdots \\
11 & \ldots\end{aligned}$ & $\begin{array}{l}\ldots \\
\cdots \\
\cdots \\
\cdots \\
\cdots \\
\cdots \\
\cdots \\
\cdots\end{array}$ & $\begin{array}{l}. \\
\ldots \\
\cdots \\
\cdots \\
\cdots \\
\cdots \\
\cdots \\
\cdots \\
\cdots\end{array}$ & $\begin{array}{r}88 \\
106 \\
110 \\
83 \\
87 \\
110 \\
67 \\
88 \\
93 \\
80 \\
133\end{array}$ & $\begin{array}{r}104 \\
94 \\
107 \\
74 \\
89 \\
123 \\
80 \\
102 \\
67 \\
80 \\
70\end{array}$ & $\begin{array}{r}105 \\
110 \\
96 \\
84 \\
102 \\
83 \\
80 \\
105 \\
52 \\
100 \\
69\end{array}$ & $\begin{array}{r}97 \\
117\end{array}$ & $\begin{array}{r}102 \\
103 \\
104 \\
80 \\
94 \\
108 \\
78 \\
98 \\
74 \\
87 \\
91\end{array}$ \\
\hline \multicolumn{8}{|c|}{ Potassium } \\
\hline $\begin{aligned} 1 & \cdots \\
2 & \cdots \\
3 & \cdots \\
4 & \cdots \\
5 & \cdots \\
6 & \cdots \\
7 & \cdots \\
8 & \cdots \\
9 & \cdots \\
10 & \cdots \\
11 & \cdots\end{aligned}$ & $\begin{array}{l}\cdots \\
\cdots \\
\cdots \\
\cdots \\
\cdots \\
\cdots \\
\cdots \\
\cdots\end{array}$ & $\begin{array}{l}. \\
\cdots \\
\cdots \\
\cdots \\
\cdots \\
\cdots \\
\cdots \\
\cdots \\
\therefore\end{array}$ & $\begin{array}{r}10 \cdot 6 \\
6 \cdot 2 \\
6 \cdot 0 \\
10 \cdot 6 \\
8 \cdot 4 \\
9 \cdot 0 \\
9 \cdot 2 \\
11 \cdot 6 \\
21 \cdot 0 \\
9 \cdot 6 \\
5 \cdot 3\end{array}$ & $\begin{array}{r}11.2 \\
7.2 \\
6.5 \\
17.0 \\
15.0 \\
6.2 \\
9.5 \\
10.0 \\
19.0 \\
20.0 \\
7.6\end{array}$ & $\begin{array}{r}7 \cdot 6 \\
12 \cdot 0 \\
6 \cdot 1 \\
10 \cdot 4 \\
7 \cdot 2 \\
14 \cdot 8 \\
9 \cdot 5 \\
8 \cdot 8 \\
16 \cdot 0 \\
9 \cdot 4 \\
9 \cdot 0\end{array}$ & $\begin{array}{l}8 \cdot 0 \\
7.8\end{array}$ & $\begin{array}{r}9 \cdot 2 \\
8.5 \\
6 \cdot 2 \\
12.7 \\
9.7 \\
9.5 \\
9 \cdot 4 \\
10 \cdot 1 \\
18 \cdot 7 \\
12.7 \\
7.3\end{array}$ \\
\hline \multicolumn{8}{|c|}{ Chloride } \\
\hline $\begin{aligned} 1 & \cdots \\
2 & \cdots \\
3 & \cdots \\
4 & \cdots \\
5 & \cdots \\
6 & \cdots \\
7 & \cdots \\
8 & \cdots \\
9 & \cdots \\
10 & \cdots \\
11 & \cdots\end{aligned}$ & $\begin{array}{l}\ldots \\
\cdots \\
\cdots \\
\cdots \\
\cdots \\
\cdots \\
\cdots \\
\cdots \\
\cdots\end{array}$ & $\begin{array}{l}. \\
\cdots \\
\cdots \\
\cdots \\
\cdots \\
\cdots \\
\cdots \\
\cdots\end{array}$ & $\begin{array}{l}141 \\
136 \\
139 \\
132 \\
128 \\
137 \\
116 \\
115 \\
100 \\
129 \\
118\end{array}$ & $\begin{array}{r}143 \\
137 \\
97 \\
149 \\
140 \\
140 \\
103 \\
120 \\
136 \\
137 \\
140\end{array}$ & $\begin{array}{r}152 \\
128 \\
93 \\
144 \\
123 \\
133 \\
116 \\
126 \\
121 \\
129 \\
140\end{array}$ & $\begin{array}{l}147 \\
\\
140 \\
105\end{array}$ & $\begin{array}{l}146 \\
137 \\
110 \\
141 \\
124 \\
137 \\
112 \\
120 \\
119 \\
132 \\
133\end{array}$ \\
\hline
\end{tabular}

Such oedema must delay the return of active intestinal motility necessary for the resumption of oral feeding. If large infusions of saline are necessitated by large gastrointestinal losses, more serious difficulties such as pulmonary oedema may result, especially if renal function is impaired. Failure to replace potassium losses as they occur may lead to subclinical hypopotassaemia, again with delay in return of bowel function. It may be pointed out that the serum potassium concentration may apparently be normal while the total exchangeable potassium is considerably reduced, with low concentration in the cells. The method of replacement suggested by Randall (1967) and by Cooke and Crowley (1952) are difficult to apply, since gastrointestinal aspirations as practised in most hospitals are never purely gastric or intestinal.

\section{TABLE V.-Recommended Gastrointestinal Replacement Solution}

Concentration of electrolytes $(\mathrm{mEq} / \mathrm{l}$.)

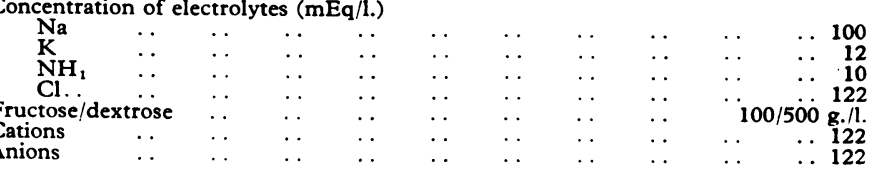

Composition: Each $100 \mathrm{ml}$. contains sodium chloride $0.59 \mathrm{~g}$., potassium chloride $0.09 \mathrm{~g}$., ammonium chloride $0.053 \mathrm{~g}$., and dextrose $5 \mathrm{~g}$., or fructose $10 \mathrm{~g}$.

As a result of this study the gastrointestinal replacement solution shown in Table $\mathrm{V}$ is recommended. The additional $10 \mathrm{mEq}$ of chloride is provided with ammonium chloride. Dextrose $5 \%$ or fructose $10 \%$ may be added to provide calories. For aspirations in peritonitis $100 \mathrm{mEq}$ of sodium is adequate, and as it is within the mean-plus-one standard deviation of the sodium concentrations of aspirations from vagotomy with drainage $(88+19.49=107.49)$, perforated duodenal ulcer $(81+19.49=100.49)$, and intestinal obstruction $(89+19.49=108.49)$, it is suitable for these as well; $12 \mathrm{mEq}$ of potassium, which is a high average, ensures adequate potassium replacement for most aspirations. In a very small group, especially in perforated duodenal ulcer, the potassium loss is likely to exceed $16 \mathrm{mEq} / \mathrm{l}$., but unless the aspirations are very excessive the supply of the daily requirements of about $40 \mathrm{mEq}$ should rectify the small deficit. It is of interest that the concentrations of sodium and chloride suggested from this study are the averages of those recommended by Cooke and Crowley (1952) for gastric and intestinal solutions.

Our current practice is to replace gastrointestinal aspirations volume for volume by this replacement solution every six hours; $500 \mathrm{ml}$. can be given in one hour. By this method serious water and electrolyte imbalances are prevented.

I acknowledge the help of the nursing staff of the department of surgery, especially those in the theatre recovery ward; of Dr. T. D. Osafo, of the department of chemical pathology, under whose supervision the electrolytes were measured; and of Mrs. B. AnkraBadu, of the biostatistics unit, Ministry of Health, Accra, who was responsible for the statistical analysis of the results.

\section{REFERENCES}

Cooke, R. E., and Crowley, L. G. (1952). New England Fournal of Medicine, 246, 637 .

Randall, H. T. (1967). In American College of Surgeons' Manual of Preoperative and Postoperative Care, p. 27. Philadelphia, Saunders. 